\title{
Toxocara canis (Werner, 1782) Eggs in the Pleistocene Site of Menez-Dregan, France (300,000-500,000 Years Before Present)
}

\author{
Françoise Bouchet $/{ }^{+}$, Adauto Araújo*, Stephanie Harter, Sérgio Miranda Chaves*, \\ Antonio Nascimento Duarte*, Jean Laurent Monnier**, Luiz Fernando Ferreira*
}

\author{
Laboratoire de Paléoparasitologie, EA 3308, associé CNRS ESA 8045, U.F.R de Pharmacie, Université de Reims, 51, rue \\ Cognacq-Jay, 51096 Reims Cedex, France *Escola Nacional de Saúde Pública-Fiocruz, Rio de Janeiro, RJ, Brasil **Civilisations \\ Atlantiques et Archéosciences, CNRS, UMR 6566, France
}

On the archaeological site of Menez-Dregan in Brittany, France, dated 300,000-500,000 years-old, paleoparasitological analysis of cave deposits led to the detection of well-preserved helminth eggs, which morphology and morphometry pointed to the diagnosis of Toxocara canis eggs, a parasite of carnivore mammals. Paleolithic remains suggested a parasitism of the hyena Crocuta spelaea or other canids that inhabited the region.

Key words: paleoparasitology - ancient parasitism - parasite fossil record - Toxocara canis - paleofauna

The archaeological site of Menez-Dregan (Plouhinec, Finistere) is a collapsed cave near the shore in Brittany. Excavations were performed since 1991 (Hallegouët et al. 1992). They revealed human occupation levels dated 300,000 to 500,000 years old (Paramagnetic Electronic Resonance) (Monnier et al. 1994, Miallier et al. 2000). Lithic artifacts were identified as "Colombanien" (Monnier \& Molines 1993), characteristic of a well-known period in Europe. Human-made hearths are associated with these old dates. Evidence indicates that fire must have been carefully maintained inside the cave. The paleoenvironment was temperate and oceanic (Monnier et al. 1996).

Sediment samples from layers 5e, 7, and 9a were examined for parasites. These layers were chosen as they revealed human remains such as lithic artifacts and preserved organic material. Fragmented bones were recovered only from the $5 \mathrm{e}$ and the $9 \mathrm{a}$ layers.

Samples were rehydrated for 5 weeks in a $0.5 \%$ aqueous trisodic phosphate solution. A 5\% glycerinated solution was added and the material was then crushed in a mortar. The suspension was treated in ultrasonic device (Sonorex $103 \mathrm{~K}$ ) at $60^{\circ} \mathrm{C}$ for $1 \mathrm{~min}$ and strained through $315-\mu \mathrm{m}, 160-\mu \mathrm{m}, 50-\mu \mathrm{m}$, and $25-\mu \mathrm{m}$ meshes. The last two screening were treated with flotation (densities 1.04 to 1.4 ) and sedimentation (1,500 rpm for $5 \mathrm{~min}$ ) techniques (Bouchet et al. 2001).

Pollen recovery was performed using the classical chemical method adapted for this kind of sample (HF 50\%, $\mathrm{HCl} 50 \%$, and $\mathrm{KOH} 10 \%$ ). After chemical treatment flotation process was performed in dense liquid medium $\left(\mathrm{ZnCL}_{2}\right)$, required for the concentration of the spores and pollen grains from the residues of the sediment.

Supported by CNPq, Papes/Fiocruz, CNRS and Capes/Cofecub. ${ }^{+}$Corresponding author. Fax: (33)(0)3 269135 47. E-mail: francoise.bouchet@univ-reims.fr

Received 26 August 2002

Accepted 25 November 2002
Parasite eggs were found only in the sedimentation preparations. Eggs were identified by their morphology and morphometry. Because there are no Pleistocene references they were compared to the local modern parasitic fauna (Chame 1992). For extinct animals, parasite checklists of related hosts were also examined.

Helminth eggs were identified in the 7th layer sediment. Rounded nematode eggs measuring $90 \mu \mathrm{m}$ in diameter with a thick, rough corrugated shell were identified as Toxocara eggs (Nematoda, Ascarididae) (Fig. 1).

Toxocara species are commonly found in wild and domestic animals. The eggs are identified by their thick corrugated shell, size and shape: Neoascaris vitulorum (Goeze, 1782), in cattle (egg size - $75 \mu \mathrm{m}$ x $90 \mu \mathrm{m}$ ); Toxocara canis (Werner 1782), in Canids, dog (Canisfamiliaris), fox (Vulpes vulpes), wolf (Canis lupus), hyena (Crocuta crocuta), and other carnivore mammals (egg size $-75 \mu \mathrm{m}$ x 85-90 $\mu \mathrm{m}$ ); Toxocara cati (Werner, 1902), in felid species (egg size $-70 \mu \mathrm{m}$ x $75 \mu \mathrm{m}$ ); Toxocara mystax (Zeder, 1900) in lion (Panthera leo), leopard (Panthera pardus pardus), lynx (Lynx lynx) (egg size - 65-75 $\mu$ m diameter) (Baer 1924, Baylis 1937, Levine 1968, Warren 1971, 1972, Graber et al. 1980, Jooste 1989).

The hyena Crocuta spelea was the predominant carnivorous species during Pleistocene times in the region (Guérin \& Patou-Mathis 1996, Miskovsky 2002). This extinct species is close to present-day African spotted-hyena $C$. crocuta, which is found infected by $T$. canis, Taenia crocutae, Diphyllobothrium sp., Toxascaris sp., Cyclicospirura sp., and Dipylidium sp. (Ferreira et al. 1993). This hunter-scavenger, large, carnivore seemed to occupy the same habitat and ecological niche as humans in the past. Humans and hyenas competed directly for food and dwelling. Although containing human remains, so far no human or other animal bones were recovered from layer 7 of Menez-Dregan. However, carbonized bone fragments were found in sediment microscope examination.

Size and shape of the eggs are consistent with of $T$. canis and the paleohyena or other canid, such as the wolf, could be ascribed as potential hosts. Eggs are very well preserved especially the fine net that covers Toxocara 
eggshell, as seen in Fig. 1 (Ubelaker \& Allison 1975, Wharton 1980). Resistance to taphonomic processes may be explained by the chitinous shell structure (Ishii 1991, Bouchet \& Leger 1985, Soulsby 1982).

Palynological analysis shows semispherical-shaped grains with three pores displaced slightly from the equator into one hemisphere (Fig. 2). Morphologically they can be identified as a Carya (Juglandaceae) pollen, a temperate plant genus found in Europe during upper Pleistocene time (500,000 years).

Regarding the parasite eggs found, these are the first to be mentioned in organic sediment dated from the Pleistocene. Previously parasite eggs and larvae were found in Pleistocene coprolites (Ferreira et al. 1993, Jouy-Avantin et al. 1999). The archaeological site of Menez-Dregan shows environmental aspects different from the sites located in dry mountain regions, such as Fontana Acetosa, Costa San Giacoma, Central Italy (Ferreira et al. 1993), and La Caune d'Arago, France (Jouy-Avantin et al. 1999). It seems that the humidity of the deepest layers of MenezDregan favored the preservation of organic material, including parasite eggs, but impaired fecal mineralization. The pollen finding also attest the good preservation conditions. These findings add new data to the knowledge of parasitic infection among Pleistocene extinct hosts.

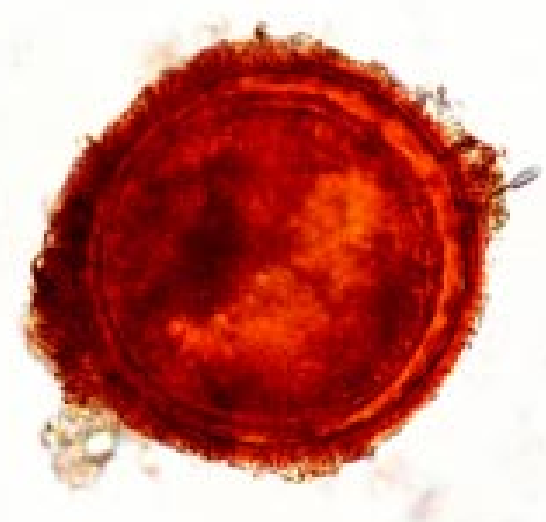

Fig. 1: Toxocara canis egg found in Menez-Dregan cave, France, dated 500,000 years-old.

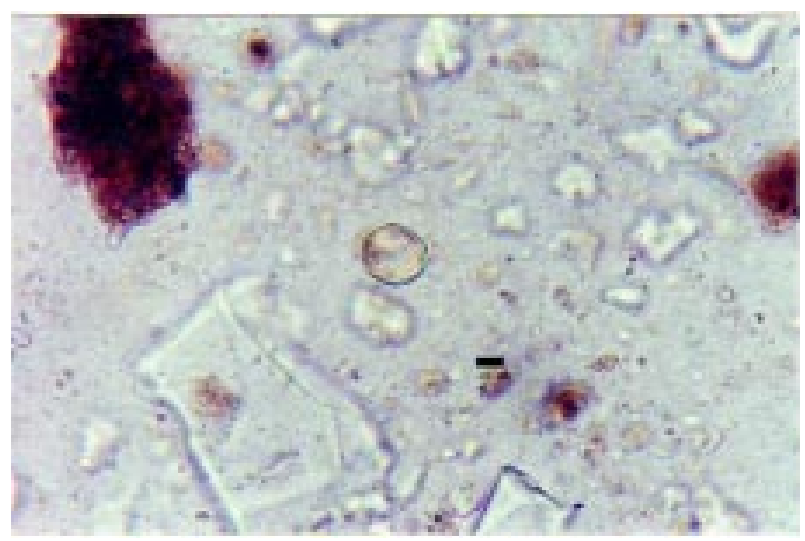

Fig. 2: Carya (Juglandaceae) Polar view (400X). Pollen from a sample collected in the Pleistocene site of Menez-Dregan, France.

\section{ACKNOWLEDGMENTS}

To Dr Claude Guérin for helping us with bibliography.

\section{REFERENCES}

Baer JG 1924. Contribution à la faune helminthologique SudAfricaine. Ann Parasitol Hum Comp 3: 239-247.

Baylis HA 1937. Records of some helminths from the spotted hyaena. Ann Mag Nat Hist 11: 625-629.

Bouchet F, Leger N 1985. Structure de l'œuf de Toxocara canis (Werner, 1782) (Nematoda-Ascaridae). Bull Soc Fr Parasitol 1: 133-138.

Bouchet F, Boulard Y, Baccam D, Leger N 1986. Ultrastructural studies of alterations induced by microwaves in Toxocara canis eggs: prophylactic interest. Parasitol Res 72: 755764.

Bouchet F, West D, Lefèvre Ch, Corbett D 2001. Identification of parasitosis in a child burial from Adak Island (Central Aleutian Islands, Alaska). C R Acad Sci Paris Sér II 324: 123-127.

Chame M 1992. Diagnóstico experimental de fezes e coprólitos não humanos no Parque Nacional Serra da Capivara-Piauí. In A Araújo \& LF Ferreira, Paleopatologia e Paleoepidemiologia: Estudos Multidisciplinares, Panorama ENSP, Rio de Janeiro, p. 185-211.

Ferreira LF, Araujo A, Duarte AN 1993. Nematode larvae in fossilized animal coprolites from Lower and Middle Pleistocene sites, Central Italy. J Parasitol 79: 440-442.

Graber M, Blanc P, Delavenay R 1980. Helminthes des animaux sauvages d'Ethiopie - Mammifères. Rev El Méd Vét Pays Trop 33: 143-158.

Guérin C, Patou-Mathis M 1996. Les Grands Mammifères Plio-Plèistocènes d'Europe, Masson, Paris, 1996.

Hallegouët B, Hinguant S, Gebhardt A, Monnier JL 1992. Le gisement Paléolithique inférieur de Ménez-Dregan 1 (Plouhinec, Finistère), Premiers résultats des fouilles. Bull Soc Préhist Fr 89: 77-81.

Ishii Y 1991. Electron Micrographs of Parasitic Helminths, Fukuoka, Japan, $83 \mathrm{pp}$.

Jooste R 1989. A checklist of the helminth parasites of the larger domestics and wild mammals of Zimbabwe. Trans Zimbabwe Sci Ass 64: 15-32.

Jouy-Avantin F, Combes C, de Lumley H, Miskovsky JC, Moné H 1999. Helminth eggs in animal coprolites from a middle Pleistocene site in Europe. J Parasitol 85: 376-379.

Levine ND 1968. Nematode Parasite of Domestic Animals and Man, Burgess Publishing Co., Minneapolis, $600 \mathrm{pp}$.

Miallier D, Pilleyre T, Sanzelle S, Tribolo C, Mercier N, Valladas N, Froget L, Reyss JL, Joron JL, Bahain JJ, Falgueres C, Laurent M 2000. Comparaison des datations par Thermoluminescence (TL) et Résonance Paramagnétique Electronique (RPE) pour le site de Menez-Dregan 1 (Finistère). Act XXIe R Int Arch Hist d'Antibes, p. 261-277.

Miskovsky JC 2002. Géologie de la Préhistoire, Association pour l'Etude de l'Environnement Géologique de la Préhistoire, Paris, 1519 pp.

Monnier JL, Molines N 1993. Le "Colombanien": un faciès régional du Paléolithique inférieur sur le littoral armoricanoatlantique. Bull Soc Préhist Fr 90: 283-294.

Monnier JL, Hallégouët B, Hinguant S, Van Vliet-Lanoe B, Falgueres C, Laurent M, Bahain JJ, Marguerie D, Mercier N, Geigl EM, Molines N 1996. Menez-Dregan (Plouhinec, Finistère) et le Paléolithique inférieur de l'ouest de la France. Act XIIIle Congr Un Int Sci Préhist Protohist, Forli, Italie, p. 99-108.

Monnier JL, Hallégouët B, Hinguant S, Laurent M, Auguste P, 
Bahain JJ, Falguères Ch, Gebhardt A, Marguerie D, Molines N, Morzadec H, Yokoyama Y 1994. A new regional group of the Lower Palaeolithic in Brittany (France), recently dated by Electron Spin Resonance. C R Acad Sci Paris Sér II 319: 155-160.

Soulsby EJL 1982. Helminths, Arthropods and Protozoa of Domesticated Animals, Baillière Tindall, London, 809 pp. Ubelaker A, Allison VF 1975. Scanning electron microscopy of the eggs of Ascaris lumbricoides, Ascaris suum, Toxocara canis and mystax. J Parasitol 61: 802-807.

Warren EG 1971. A new species of Toxocara from hyenas. Parasitology 62: 171-176.

Warren EG 1972. Some hosts of ascaridoid nematodes in Africa. Ann Parasitol Hum Comp 47: 763-764.

Wharton DA 1980. Nematode egg-shells. Parasitology 81: 447463. 